\title{
GEOMETRY OF THE PASSIONS
}

Fear, Hope, Happiness: Philosophy and Political Use

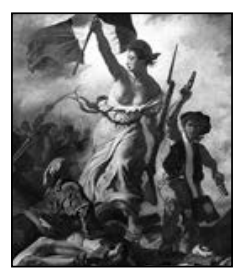


THE LORENZO DA PONTE ITALIAN LIBRARY

General Editors

Luigi Ballerini \& Massimo Ciavolella

University of California at Los Angeles

\author{
Honorary Chairs \\ Ambassador Gianfranco Facco Bonetti \\ Dr Berardo Paradiso \\ Honourable Anthony J. Scirica
}

Advisory Board

Remo Bodei, Università di Pisa

Lina Bolzoni, Scuola Normale Superiore di Pisa

Francesco Bruni, Università di Venezia

Cesare De Michelis, Università di Padova

Giorgio Ficara, Università di Torino

Giuseppe Mazzotta, Yale University

Gilberto Pizzamiglio, Università di Venezia

Margaret Rosenthal, University of Southern California

John Scott, University of Western Australia

Elissa Weaver, University of Chicago

Agincourt Ltd Board of Trustees

Luigi Ballerini

Vivian Cardia

Maria Teresa Cometto

Nicholas Gravante

Lorenzo Lagnoloni

Lorenzo Mannelli

Eugenio Nardelli

Berardo Paradiso

Silvana Riggio

Nicola Tegoni

Diego Rodino di Miglione

Giorgio Van Straten 


\section{THE LORENZO DA PONTE ITALIAN LIBRARY}

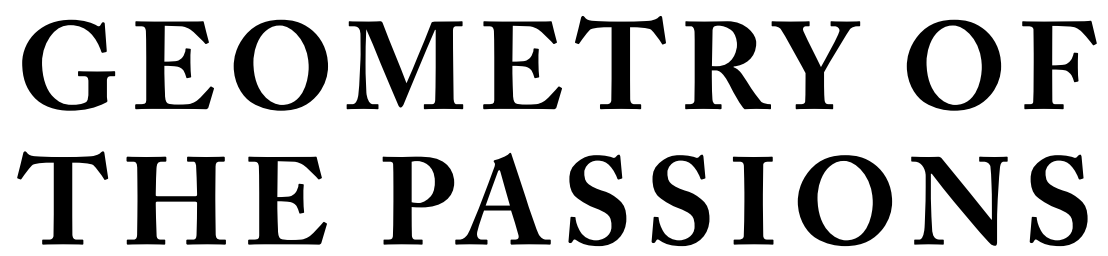

Fear, Hope, Happiness: Philosophy and Political Use

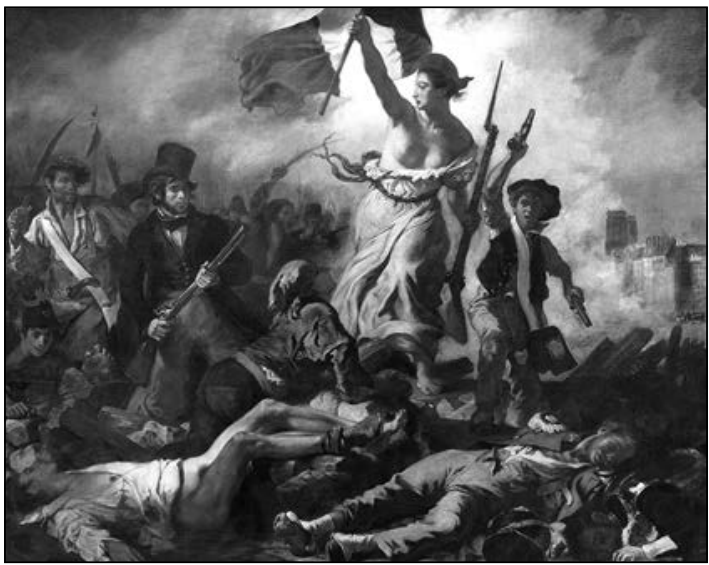

Remo Bodei

TRANSLATED BY GIANPIERO W. DOEBLER 
(C) University of Toronto Press 2018

Toronto Buffalo London

utorontopress.com

Printed in the U.S.A.

ISBN 978-1-4875-0336-9

๑) Printed on acid-free, $100 \%$ post-consumer recycled paper with vegetable-based inks.

The Lorenzo Da Ponte Italian Library

Copyright (C) Giangiacomo Feltrinelli Editore, 1994

First published as Geometria delle passioni in January 1994

by Giangiacomo Feltrinelli Editore, Milan, Italy

\section{Library and Archives Canada Cataloguing in Publication}

Bodei, Remo, 1938-

[Geometria delle passioni. English]

Geometry of the passions : fear, hope, happiness : philosophy and political use /

Remo Bodei ; translated by Gianpiero W. Doebler.

(Lorenzo da Ponte Italian library)

Translation of: Geometria delle passioni.

Includes bibliographical references and index.

ISBN 978-1-4875-0336-9 (cloth)

1. Emotions. I. Title. III. Title: Geometria delle passioni.

English V. Series: Lorenzo da Ponte Italian library.

B815.B6413 $2018 \quad$ 128'.37 C2018-901340-0

This volume is published with the assistance of the Franklin D. Murphy Chair in Italian Renaissance Studies at the University of California, Los Angeles.

University of Toronto Press acknowledges the financial assistance to its publishing program of the Canada Council for the Arts and the Ontario Arts Council, an agency of the Government of Ontario.

\section{Canada Council Conseil des Arts for the Arts \\ du Canada}

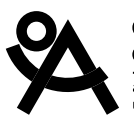

ONTARIO ARTS COUNCIL CONSEIL DES ARTS DE L'ONTARIO

an Ontario government agency un organisme du gouvernement de l'Ontario Funded by the
Government of Canada
Financé par le gouvernement du Canada 